\begin{tabular}{|c|c|}
\hline 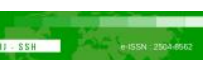 & Malaysian Journal of Social Sciences and Humanities (MJSSH) \\
\hline Malaysian Journal of & Volume 6, Issue 3, March 2021 \\
\hline (MJ-sSH) & e-ISSN : 2504-8562 \\
\hline & $\begin{array}{l}\text { Journal home page: } \\
\text { www.msocialsciences.com }\end{array}$ \\
\hline
\end{tabular}

\title{
Kebimbangan Matematik dan Hubungannya dengan Pencapaian Pelajar Tingkatan Satu
}

\author{
Chan Ching Peng ${ }^{1}$, Roslinda Rosli ${ }^{1}$ \\ ${ }^{1}$ Fakulti Pendidikan, Universiti Kebangsaan Malaysia (UKM) \\ Correspondence: Chan Ching Peng (p99518@siswa.ukm.edu.my)
}

\begin{abstract}
Abstrak
Perasaan takut dan tertekan semasa berhadapan dengan kegiatan melibatkan matematik, atau lebih dikenali sebagai kebimbangan matematik, mungkin boleh menjejaskan pembelajaran dan kehidupan harian pelajar. Pada masa yang sama, pelajar yang menonjolkan simptom kebimbangan matematik tidak semestinya mendapat keputusan peperiksaan yang lemah. Kajian tinjauan ini bertujuan untuk meninjau tahap kebimbangan matematik pelajar tingkatan satu dan hubungannya dengan pencapaian pelajar dalam matematik. Responden kajian terdiri daripada 140 orang pelajar tingkatan satu yang dipilih secara rawak sistematik dari sebuah sekolah di Daerah Petaling. Kajian kuantitatif ini menggunakan instrumen soal selidik Mathematics Anxiety Scale-UK (MAS-UK) bagi mengukur tahap kebimbangan matematik pelajar dan hubungannya dengan pencapaian matematik pelajar. Data dianalisis secara deskriptif dengan merujuk kepada skor min dan inferensi menggunakan Korelasi Spearman rho. Dapatan kajian menunjukkan bahawa tahap kebimbangan pelajar tingkatan satu terhadap matematik adalah sederhana. Analisis inferensi menunjukkan tidak terdapat hubungan yang signifikan antara tahap kebimbangan matematik dengan pencapaian matematik pelajar tingkatan satu. Walaupun tahap kebimbangan adalah sederhana, pengesanan awal harus dijalankan agar dapat memberikan intervensi yang bersesuaian dan meningkatkan keyakinan serta minat pelajar terhadap subjek Matematik.
\end{abstract}

Kata kunci: kebimbangan matematik, kegelisahan, fobia, prestasi, menengah rendah

\section{Mathematics Anxiety and its Relationship with the Achievement of Form One Students}

\begin{abstract}
The feelings of fear and stressed while being confronted with activities involving mathematics, or better known as mathematics anxiety, can affect a student's learning and daily life. At the same time, students who portrayed symptoms of mathematics anxiety might not attain low achievement in examinations. The purpose of this study is to identify mathematics anxiety level of form one students and its relationship with students' achievement in mathematics. Respondents consisted of 140 form one students from a secondary school in Petaling District. This quantitative research applied Mathematics Anxiety Scale-UK (MAS-UK) questionnaire to measure the level of mathematics anxiety and its relationship with students' mathematics achievement. Data was analysed descriptively by referring to mean score and inferentially by using Spearman rho Correlation Test. Results showed that form one students have moderate mathematics anxiety level. Inferential analysis showed that there is no significant relation between mathematics anxiety level and students' achievement in mathematics. Although the level of mathematics
\end{abstract}


anxiety is moderate, early detection should be carried out in order to provide suitable intervention for these students and to increase their confidence and interest in mathematics.

Keywords: mathematics anxiety, anxious, phobia, performance, lower secondary

\section{Pengenalan}

Dalam meniti arus pemodenan, sistem pendidikan negara mengalami perubahan untuk menyediakan pelajar yang berkaliber dan berdaya saing di persada dunia. Daripada Kurikulum Bersepadu Sekolah Rendah (KBSR), sukatan pelajaran ditambahbaikkan menjadi Kurikulum Standard Sekolah Rendah (KSSR) pada tahun 2011 dan kemudian kepada KSSR Semakan pada tahun 2015. Kurikulum di peringkat sekolah menengah turut ditukar daripada Kurikulum Bersepadu Sekolah Menengah (KBSM) kepada Kurikulum Standard Sekolah Menengah (KSSM) pada tahun 2017. Penambahbaikan ini mengambil kira kemahiran relevan yang perlu dikuasai oleh pelajar mengikut permintaan dunia pekerjaan yang semakin sengit. Penerapan matematik dalam kehidupan harian tidak dapat dinafikan lagi. Namun demikian, terdapat juga pelajar mengelakkan daripada memilih jurusan sains atau pekerjaan yang melibatkan kegiatan matematik kerana fobia terhadap mata pelajaran tersebut (Rameli \& Kosnin, 2016; Yahya \& Amir, 2018).

Fobia terhadap matematik atau lebih dikenali sebagai kebimbangan matematik wujud dalam kalangan pelajar, terutamanya mereka yang mendapat pencapaian matematik yang rendah (Organisation for Economic Cooperation and Development, 2013). Individu yang menghadapi kebimbangan matematik akan dilanda perasaan tertekan dan gelisah semasa melaksanakan pengiraan melibatkan nombor dan menyelesaikan masalah matematik, tidak kira dalam kehidupan harian ataupun sewaktu sesi pengajaran dan pembelajaran (PdP) (Dowker, Sarkar \& Looi, 2016; Hunt \& Zakaria, 2018; Prodromou \& Frederiksen, 2018). Keadaan bertambah buruk apabila sesetengah pelajar mempunyai persepsi negatif terhadap subjek ini. Mereka tidak dapat menghubungkaitkan konsep yang dipelajari dengan aktiviti harian (Yahya \& Amir, 2018). Pelajar didedahkan kepada konsep yang lebih kompleks apabila mereka melangkah ke peringkat sekolah menengah dan universiti. Sebagai akibatnya, emosi negatif ini akan lebih menonjol dan semakin bertambah apabila usia mereka meningkat. Secara tidak langsung, minat pelajar terhadap matematik turut terjejas.

Pada masa yang sama, perasaan takut ini juga berhubung kait dengan pencapaian matematik pelajar (Delgado, Espinoza \& Fonseca, 2017; Juniati \& Budayasa, 2020; Mutlu, 2019; Puteh \& Khalin, 2016). Pelajar dengan tahap kebimbangan matematik yang tinggi didapati mempunyai keputusan matematik yang rendah. Hal ini kerana pelajar menggunakan teknik menjawab yang paling mudah dan cepat untuk menyelesaikan soalan yang diberi. Mereka berbuat demikian untuk memastikan tidak perlu berhadapan dengan perasaan takut setelah menjawab soalan-soalan tersebut (Carey et al., 2016). Walau bagaimanapun, pelajar dengan keputusan cemerlang dalam matematik juga tidak terkecuali daripada mengalami kebimbangan matematik. Harapan tinggi ibu bapa, guru dan masyarakat sedikit sebanyak memberi kesan kepada pelajar-pelajar ini (Rameli \& Kosnin, 2016). Mereka terdesak untuk mendapatkan keputusan yang baik sehingga timbul perasaan takut apabila berhadapan dengan aktiviti matematik. Oleh itu, kebimbangan matematik bukan sahaja dihadapi oleh pelajar yang lemah, malah turut menjejaskan pelajar cemerlang.

Kebimbangan matematik yang tidak ditangani akan terbawa sehingga ke alam pekerjaan. Secara tidak langsung, ibu bapa yang menonjolkan perasaan takut terhadap subjek ini turut mempengaruhi persepsi anak-anak dan seterusnya menimbulkan kebimbangan matematik dalam kalangan anak mereka (Prahmana, 2019; Yahya \& Amir, 2018; Yavuz, 2018). Oleh itu, pengesanan awal fobia terhadap matematik dapat membantu pelajar menangani masalah ini dengan lebih berkesan. Pelajar yang menghadapi masalah dalam matematik dapat mengenali dan memahami punca perasaan takut mereka. Dengan berpegang kepada pengetahuan tentang masalah mereka, pelajar boleh mendapatkan bantuan yang sewajarnya untuk mengatasi perasaan takut ini. Tambahan pula, kajian ke atas kebimbangan 
matematik memberikan pendedahan kepada guru dan ibu bapa tentang situasi pelajar (Carey et al., 2019; Prahmana, 2019; Yavuz, 2018). Pendedahan ini membantu guru dalam perancangan PdP yang bersesuaian. Ibu bapa pula boleh meneroka lebih maklumat mengenai kebimbangan matematik untuk membantu diri dan juga anak memandangkan penerapan matematik tidak dapat dielakkan dalam kehidupan harian.

Secara amnya, kajian ini bertujuan untuk meninjau tahap kebimbangan matematik dalam kalangan pelajar tingkatan satu dan hubungan antara kebimbangan matematik dengan pencapaian pelajar tingkatan satu dalam matematik. Penambahbaikan sukatan pelajaran dari KBSM kepada KSSM melihat perubahan ketara bagi mata pelajaran Matematik (Kementerian Pendidikan Malaysia, 2015). Isi kandungan baru kini lebih berfokus kepada kemahiran berfikir aras tinggi dan beberapa topik tingkatan dua dan tingkatan tiga yang dibawa ke hadapan. Pengenalan kepada konsep matematik makin kompleks akan memberi impak kepada pelajar baru melangkah ke sekolah menengah. Tanpa penguasaan kemahiran asas matematik yang kukuh, pelajar berasa tertekan dan tidak berupaya untuk mengikuti sukatan peringkat seterusnya. Oleh itu, pengesanan kebimbangan matematik membolehkan pelajar mendapatkan bantuan yang bersesuaian. Pengurangan kebimbangan ini memberi peluang kepada pelajar menikmati keindahan matematik di samping meningkatkan keyakinan mereka terhadap subjek ini.

\section{Sorotan Literatur}

\section{Kebimbangan Matematik}

Kebimbangan matematik mula dikaji sejak tahun 1957 oleh Dreger dan Aiken (Dowker, Sarkar \& Looi, 2016). Semenjak pembinaan instrumen Mathematics Anxiety Rating Scale (MARS) oleh Richardson dan Suinn pada tahun 1972, instrumen ini membantu ramai pengkaji dalam mengukur tahap kebimbangan matematik. Pelbagai versi instrumen telah diubahsuai agar bersesuaian dengan populasi kajian masingmasing. Kebimbangan matematik merujuk kepada perasaan gelisah, takut dan tertekan apabila individu berhadapan dengan kegiatan yang melibatkan operasi matematik (Dowker, Sarkar \& Looi, 2016; Hunt \& Zakaria, 2018; Mandal, 2020; Prodromou \& Frederiksen, 2018). Keadaan ini bukan sahaja secara emosi, malah akan menjejaskan individu secara fizikal dan mental. Pelajar yang menghadapi kebimbangan matematik akan berpeluh, menggigil dan menunjukkan peningkatan kadar denyutan jantung semasa melibatkan diri dalam aktiviti matematik (Puteh \& Khalin, 2016). Fobia terhadap subjek ini bertambah teruk sehingga menyebabkan pelajar cuba mengelakkan aktiviti yang melibatkan konsep matematik sama ada dalam kehidupan harian, kelas ataupun di alam pekerjaan.

Walaupun didedahkan kepada soalan yang mudah, pelajar dengan kebimbangan matematik tidak dapat memproses kehendak soalan. Mereka bertanggapan soalan-soalan matematik akan menyebabkan mereka berasa takut, bosan dan memeningkan kerana dipenuhi oleh konsep yang abstrak (Deringol, 2018; Mustaffa, 2017). Pelajar juga didapati memaparkan simptom kebimbangan yang lebih jelas apabila dikehendaki menyelesaikan soalan melibatkan ayat matematik dan algebra (Prodromou \& Frederiksen, 2018; Puteh \& Khalin, 2016). Disebabkan oleh kecenderungan berfikir negatif apabila berhadapan dengan soalan matematik, pelajar menghadapi kesukaran untuk menerima maklumat yang disampaikan oleh guru sewaktu PdP. Menurut Mutlu (2019), perasaan gementar semasa menyelesaikan tugasan melibatkan pengiraan adalah berhubung kait dengan pemprosesan maklumat secara kognitif dalam otak. Mereka berasa tidak terdaya dan minat turut menurun kerana perlu meluangkan lebih masa untuk memahami konsep yang diajar. Hal ini menyebabkan pelajar mengambil jalan singkat semasa menjawab latihan atau ujian matematik. Mereka jarang mengambil inisiatif untuk memastikan teknik menjawab adalah betul kerana ingin mengelakkan diri daripada dibelenggu oleh perasaan takut (Carey et al., 2016).

\section{Model Kebimbangan Matematik dan Pencapaian Matematik}

Model yang dirujuk dalam menerangkan hubungan antara kebimbangan matematik dengan pencapaian akademik pelajar ialah Delibitating Anxiety Model (Carey et al., 2016, 2019). 
Rajah 1: Delibitating Anxiety Model

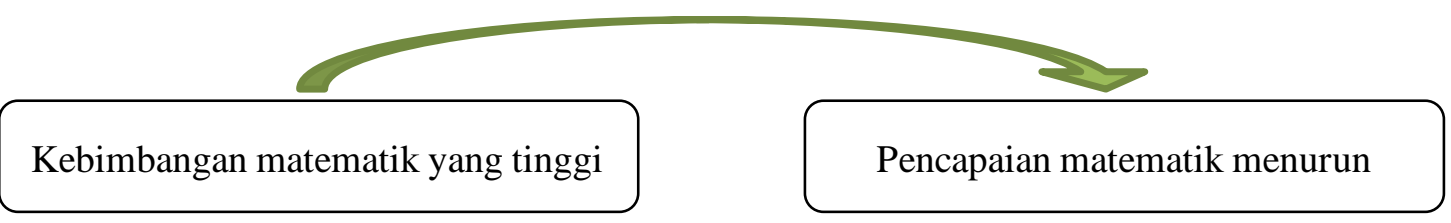

Sumber: Diadaptasi daripada kajian Carey et al. (2016)

Berdasarkan Delibitating Anxiety Model, kebimbangan matematik yang keterlaluan sewaktu mempelajari dan mengingat kembali kemahiran matematik menyebabkan pencapaian matematik pelajar menurun. Memori kerja (working memory) pelajar dengan kebimbangan matematik adalah terhad dan memerlukan masa yang lebih lama untuk mengimbas kembali konsep yang telah dipelajari. Oleh sebab itu, sesetengah pelajar dengan kebimbangan matematik akan mengambil langkah mudah dengan menjawab soalan dengan segera walaupun jawapan adalah tidak betul. Menurut Carey et al. (2016), model ini adalah lebih jelas dalam kalangan orang dewasa yang mengalami fobia terhadap matematik. Walaupun kaedah penyelesaian yang digunakan adalah kurang efektif, mereka memilih strategi yang lebih mudah untuk menjawab soalan. Hal ini secara tidak langsung menjejaskan prestasi matematik mereka disebabkan oleh fobia terhadap subjek Matematik.

\section{Faktor-faktor Kebimbangan Matematik}

Sesi pembelajaran melibatkan pemprosesan dan penyimpanan maklumat dan ia dikaitkan dengan memori kerja individu (Carey et al., 2016; Dowker, Sarkar \& Looi, 2016; Juniati \& Budayasa, 2020; Mutlu, 2019; Passolunghi, Caviola, De Agostini, Perin \& Mammarella, 2016; Yahya \& Amir, 2018). Memori kerja merujuk kepada sistem kognitif yang terlibat dalam mengekalkan dan memproses maklumat (Bayliss et al., seperti yang dinyatakan di Juniati \& Budayasa, 2020). Maklumat yang diterima akan digunakan untuk menyelesaikan soalan dan latihan yang diberi. Sekiranya individu mempunyai kapasiti peringatan rendah, mereka menghadapi masalah dalam mengimbas kembali konsep yang telah dipelajari. Kapasiti memori kerja meningkat selaras dengan peningkatan usia pelajar. Hal ini bermakna pelajar berupaya mengekalkan dan mengingati suatu pelajaran dengan baik. Oleh sebab itu, kandungan pelajaran menjadi lebih kompleks apabila pelajar melangkah ke peringkat persekolahan yang seterusnya. Walau bagaimanapun, memori kerja bagi pelajar yang mengalami kebimbangan matematik adalah terhad berbanding dengan pelajar yang setaraf dengan mereka (Mutlu, 2019). Memori mereka menjadi terbeban dengan soalan berbentuk abstrak dan ayat matematik. Mereka jauh ketinggalan dalam pembelajaran memandangkan keupayaan mereka memproses dan menyimpan maklumat adalah kurang daripada pelajar lain.

Selain itu, psikologi pelajar turut menyumbang kepada kegelisahan matematik (Yahya \& Amir, 2018). Perasaan negatif setiap kali berhadapan dengan masalah melibatkan matematik akan melumpuhkan keupayaan pelajar berfikir dengan jelas. Mereka kerap kali dilanda perasaan takut, cemas, tertekan dan pening apabila melihat nombor dan pengiraan. Pada masa yang sama, persekitaran pelajar seperti perspektif dan tekanan ibu bapa serta guru akan mengakibatkan kebimbangan matematik dalam pelajar. Menurut Lee (2009), pelajar di negara Asia seperti Jepun dan Korea mempunyai tahap kebimbangan matematik yang lebih tinggi berbanding dengan negara Eropah yang lain. Hal ini kerana sesetengah negara maju memberikan penekanan tinggi ke atas kepentingan matematik dan pencapaian akademik. Keadaan bertambah buruk apabila masyarakat menggunakan keputusan peperiksaan sebagai penanda aras kejayaan seseorang pelajar. Hal ini menyumbang kepada perasaan takut dan cemas, bukan sahaja dalam kalangan pelajar aliran Sains, malah dalam kumpulan pelajar aliran Sastera (Rameli \& Kosnin, 2016).

Menurut Hunt dan Zakaria (2018), tahap kebimbangan matematik meningkat selari dengan umur pelajar. Secara tidak langsung, ibu bapa atau guru tidak terkecuali daripada mengalami kebimbangan matematik. Pelajar akan terpengaruh oleh fobia ibu bapa dan guru sehingga menyebabkan mereka turut terjejas dan timbul perasaan takut terhadap matematik (Dowker, Sarkar \& Looi, 2016; Yahya \& Amir, 2018). 
Sekiranya pelajar kerap didedahkan kepada guru yang mempunyai simptom kebimbangan matematik, secara tidak langsung menyebabkan pelajar turut mengalami situasi yang sama. Namun demikian, Hunt dan Zakaria (2018) turut mendapati bahawa pelajar yang memperoleh bimbingan dan sokongan daripada ibu bapa mempunyai tahap kebimbangan matematik lebih rendah daripada pelajar yang tidak dibimbing oleh ibu bapa. Persekitaran positif memberi keyakinan kepada pelajar untuk mencuba dan mengurangkan potensi berlakunya kebimbangan matematik.

\section{Hubungan antara Kebimbangan Matematikdengan Pencapaian Matematik Pelajar}

Pelajar dengan kebimbangan matematik didapati menunjukkan prestasi matematik yang lebih rendah daripada pelajar lain (OECD 2013). Dapatan kajian Mustaffa (2017), Deringol (2018), Yahya dan Amir (2018) serta Mandal (2020) juga menunjukkan korelasi negatif antara kebimbangan matematik dengan pencapaian matematik pelajar. Hal ini sedikit sebanyak disebabkan oleh memori kerja pelajar dengan kebimbangan matematik yang terhad. Apabila pelajar tidak berupaya mengingati konsep yang dipelajari, mereka berasa takut dan tertekan kerana gagal menjawab soalan melibatkan operasi matematik. Walaupun memori kerja pelajar sepatutnya berkembang mengikut umur, pelajar dengan kebimbangan matematik berasa terbeban dengan nombor kompleks dan mengambil masa lebih lama untuk mencari jalan penyelesaian (Carey et al., 2016; Dowker, Sarkar \& Looi, 2016). Perasaan tidak menyenangkan ini menjurus kepada penurunan keyakinan diri pelajar dalam menjawab soalan peperiksaan. Tanggapan negatif ini juga menyebabkan pelajar cuba mengelakkan diri daripada terlibat dalam aktiviti melibatkan matematik (Carey et al., 2016; Dowker, Sarkar \& Looi, 2016; Hunt \& Zakaria, 2018). Kesannya, pencapaian matematik pelajar terjejas disebabkan oleh kebimbangan yang keterlaluan terhadap subjek ini.

Menurut Deringol (2018), pelajar hilang keyakinan diri sewaktu bersemuka dengan matematik kerana mereka diselubungi oleh perasaan takut dan cemas. Keadaan ini seterusnya menyebabkan pelajar tidak dapat menumpukan perhatian dalam tugasan matematik. Mereka menghadapi kegagalan dalam mengingat kembali konsep yang telah dipelajari. Sebagai akibatnya, pelajar menggunakan jalan mudah dan hanya fokus kepada menyelesaikan latihan atau ujian tanpa memikirkan ketepatan jawapan mereka. Terdapat juga pelajar yang memerlukan masa lebih panjang untuk menjawab soalan tetapi jalan kerja yang diberi adalah tidak sempurna dan sering terdapat kesilapan pengiraan (Dowker, Sarkar \& Looi, 2016). Secara tidak langsung, prestasi matematik mereka turut terjejas. Apabila tahap kebimbangan pelajar makin meningkat, keputusan pelajar menjadi semakin rendah.

Namun demikian, terdapat juga kajian yang menunjukkan tiada perkaitan antara kebimbangan matematik dengan pencapaian matematik pelajar (Husain, 2018; Mandal, 2020; Prodromou \& Frederiksen, 2018; Yahya \& Amir, 2018). Pelajar yang mendapat keputusan yang lemah tidak semestinya mengalami fobia terhadap matematik. Minat mereka terhadap subjek ini adalah lebih rendah menyebabkan mereka tidak endah terhadap pencapaian dalam matematik (Prodromou \& Frederiksen, 2018). Pada masa yang sama, sesetengah pelajar yang mendapat keputusan cemerlang turut menonjolkan simptom kebimbangan matematik (Dowker, Sarkar \& Looi, 2016). Pelajar berasa gelisah kerana penekanan yang tinggi daripada ibu bapa dan masyarakat. Keinginan mereka mendapat kemenangan mewujudkan kebimbangan matematik dalam kalangan pelajar ini. Walaupun mereka berupaya menjawab soalan matematik dengan tepat, penekanan kepada subjek ini dan pencapaian akademik pelajar di negara-negara membangun telah menyumbang kepada tahap kebimbangan matematik tinggi dalam kalangan pelajar ini. Kesimpulannya, kegelisahan yang melanda pelajar semasa mengambil bahagian dalam aktiviti melibatkan matematik tidak harus dipandang enteng. Pengesanan dan pencegahan adalah penting dalam membantu pelajar mengatasi masalah ini.

\section{Metod Kajian}

\section{Reka Bentuk Kajian}

Kajian ini menggunakan reka bentuk tinjauan bagi mengenal pasti tahap kebimbangan matematik pelajar tingkatan satu dan hubungan antara tahap kebimbangan matematik dengan pencapaian matematik pelajar 
tingkatan satu. Keputusan subjek Matematik dalam Ujian Pencapaian Sekolah Rendah (UPSR) tahun 2019 digunakan sebagai rujukan pencapaian pelajar. Pada masa yang sama, borang soal selidik digunakan untuk menilai tahap kebimbangan pelajar terhadap matematik. Dapatan kajian kuantitatif yang menyeluruh membolehkan dapatan dianalisis secara inferensi untuk membuat generalisasi tentang isu yang dibincangkan (Chua, 2014b).

\section{Responden Kajian}

Bagi penyelidikan ini, populasi kajian terdiri daripada 183 orang pelajar tingkatan satu Sekolah Menengah Kebangsaan Seksyen 4 Kota Damansara di daerah Petaling. Dengan merujuk kepada Jadual Penentuan Saiz Sampel Krejcie dan Morgan (Krejcie \& Morgan, 1970) dan kemungkinan responden tercicir (Chua, 2014b), seramai 140 orang pelajar tingkatan satu telah dipilih secara rawak sistematik. Responden tercicir merujuk kepada responden yang berpindah atau tidak mengambil bahagian dalam kajian tanpa makluman. Pemilihan lebih banyak responden juga dapat mengelakkan kekurangan data disebabkan oleh instrumen yang tidak lengkap atau hilang selepas tapisan data dilakukan. Selain itu, kaedah pensampelan rawak sistematik diaplikasikan bagi mengelakkan bias kajian dan ralat pengukuran. Memandangkan bilangan responden yang terlibat adalah ramai, kaedah pensampelan ini menjimatkan masa pengkaji sewaktu pemilihan responden. Responden juga boleh mewakili populasi secara keseluruhan kerana terdiri daripada jantina dan bangsa yang berlainan.

\section{Instrumen Kajian}

Instrumen kajian terdiri daripada borang soal selidik yang dibahagikan kepada dua bahagian, iaitu Bahagian A dan Bahagian B. Maklumat seperti demografi dan keputusan matematik dalam UPSR responden diperoleh di Bahagian A. Keputusan matematik UPSR tahun 2019 digunakan sebagai penanda pencapaian matematik responden kerana ujian tersebut adalah selaras untuk semua pelajar. Bahagian B pula terdiri daripada instrumen soal selidik yang mengukur tahap kebimbangan matematik dan diadaptasi daripada kajian Hunt, Clark-Carter dan Sheffield (2011). Pengkaji Hunt, Clark-Carter dan Sheffield telah mengubahsuai Mathematics Anxiety Rating Scale (MARS) yang dibina oleh Richardson dan Suinn pada tahun 1972 kepada MAS-UK. Daripada 98 item dalam MARS, soal selidik dipendekkan kepada 23 item dalam MAS-UK. Bahagian ini mempunyai tiga konstruk, iaitu kebimbangan dalam penilaian matematik, kebimbangan matematik dalam sosial atau kehidupan harian dan kebimbangan dalam pemerhatian matematik. Setiap konstruk mempunyai enam hingga sembilan item yang melibatkan situasi kehidupan harian dan pilihan jawapan adalah dalam bentuk skala Likert.

Walaupun soal selidik MAS-UK disampaikan dalam Bahasa Inggeris, item-item diterjemahkan ke Bahasa Melayu untuk mengelakkan salah tafsir oleh responden yang lemah dalam Bahasa Inggeris. Bagi mengekalkan kesahan instrumen, dua orang guru Bahasa Inggeris dan dua orang guru Bahasa Melayu dengan pengalaman mengajar bidang masing-masing lebih daripada 15 tahun menyemak hasil terjemahan. Pembetulan dibuat pada soal selidik sebelum kajian rintis dijalankan. Kajian rintis dijalankan ke atas 30 orang pelajar yang memiliki ciri yang sama dengan responden kajian sebenar. Hasil kajian rintis menunjukkan kebolehpercayaan memuaskan bagi setiap konstruk, iaitu dengan nilai pekali Cronbach alpha antara 0.65 hingga 0.95 (Chua, 2014a; Darusalam \& Hussin, 2018). Secara keseluruhannya, instrumen kajian mencatatkan nilai pekali 0.892 dan mempunyai kebolehpercayaan yang memuaskan untuk mengukur tahap kebimbangan pelajar terhadap matematik. Jadual 1 menunjukkan nilai pekali Cronbach alpha mengikut konstruk dengan lebih jelas.

Jadual 1: Nilai pekali Cronbach Alpha mengikut konstruk

\begin{tabular}{lc}
\hline \multicolumn{1}{c}{ Instrumen } & Pekali Cronbach alpha \\
\hline Kebimbangan dalam penilaian matematik & .838 \\
Kebimbangan matematik dalam sosial atau kehidupan harian & .698 \\
Kebimbangan dalam pemerhatian matematik & .846 \\
Tahap kebimbangan (keseluruhan) & .892 \\
\hline
\end{tabular}




\section{Prosedur Pengumpulan dan Analisis Data}

Prosedur pengumpulan data yang teratur memudahkan pengkaji mendapatkan maklum balas daripada responden. Memandangkan negara dilanda Covid-19 dan Perintah Kawalan Pergerakan (PKP) (Majlis Keselamatan Negara, 2020), proses pengumpulan data mengambil masa lebih lama. Kajian terhadap responden hanya boleh dijalankan pada bulan Julai 2020 apabila pelajar tingkatan satu menghadiri sekolah semula. Pengumpulan data memakan masa sehingga seminggu kerana sesetengah responden tidak hadir ke sekolah atas sebab kebimbangan bilangan kes Covid-19 masih tinggi. Walaupun pengaplikasian kemudahan teknologi seperti Google Form memudahkan pengkaji mendapat semula respons dengan kadar lebih cepat, kaedah ini tidak bersesuaian dengan populasi kajian. Hal ini kerana latar belakang kewangan responden adalah berbeza dan mempunyai kekangan dalam mendapatkan capaian Internet serta peranti teknologi untuk menjawab soal selidik secara maya.

Data ditapis sebelum dianalisis menggunakan perisian Statistical Package for the Social Science (SPSS) versi 23. Kaedah statistik deskriptif dan statistik inferensi digunakan untuk menganalisis data yang diperoleh daripada kajian kuantitatif ini. Bagi menjawab kepada persoalan kajian mengenai tahap kebimbangan pelajar tingkatan satu terhadap matematik, data dianalisis secara deskriptif dengan merujuk kepada nilai skor min. Nilai yang didapati dibandingkan dengan skor min kajian yang digunakan dalam kajian Yahya dan Amir (2018).

Persoalan kedua, iaitu hubungan antara kebimbangan matematik dengan pencapaian pelajar tingkatan satu dalam matematik, dianalisis secara inferensi menggunakan ujian Korelasi Spearman rho. Walaupun Ujian Korelasi Pearson menunjukkan hubungan sebab-akibat antara pemboleh ubah kajian, pengkaji juga mengambil kira normaliti taburan data. Sekiranya taburan data adalah tidak normal, maka Ujian Korelasi Spearman rho adalah lebih bersesuaian untuk menentukan hubungan antara kebimbangan matematik dengan pencapaian matematik tingkatan satu (Chua, 2013).

\section{Hasil Kajian}

\section{Profil Responden Kajian}

Daripada 140 orang responden yang terpilih untuk menyertai penyelidikan ini, terdapat $68(48.6 \%)$ orang pelajar lelaki dan 72 (51.4\%) orang pelajar perempuan. Bilangan yang hampir sama rata antara keduadua jantina tidak memberikan kesan kepada dapatan kajian dalam tahap kebimbangan pelajar terhadap matematik. Keputusan subjek Matematik dalam UPSR tahun 2019 menunjukkan 6 (4.3\%) orang responden mendapat Gred A, diikuti oleh Gred B yang mencatatkan sebanyak 20 (14.3\%) orang responden dan Gred C sebanyak 39 (27.9\%) orang responden. Bilangan responden yang memperoleh Gred D adalah tertinggi, iaitu seramai 59 (42.1\%) orang responden dan 16 (11.4\%) orang mendapat Gred E. Kajian mendapati bahawa taburan pencapaian matematik pelajar adalah pada tahap lemah.

\section{Tahap Kebimbangan Pelajar Tingkatan Satu terhadap Matematik}

Kebimbangan pelajar tingkatan satu terhadap matematik dilihat dari tiga sudut, iaitu kebimbangan matematik dalam sosial atau kehidupan harian, kebimbangan dalam penilaian matematik dan kebimbangan dalam pemerhatian matematik. Dapatan kajian mencatatkan konstruk kebimbangan dalam penilaian matematik pada tahap sederhana, dengan skor min sebanyak 2.71. Konstruk kedua dan ketiga, iaitu kebimbangan matematik dalam sosial atau kehidupan harian dan dalam pemerhatian matematik, menunjukkan tahap kebimbangan yang rendah dengan nilai skor min 2.39 dan 2.47 masing-masing. Secara keseluruhannya, tahap kebimbangan pelajar tingkatan satu terhadap matematik adalah pada tahap sederhana, dengan nilai skor min sebanyak 2.53. Jadual 2 menunjukkan dapatan kajian tentang tahap kebimbangan pelajar tingkatan satu terhadap matematik dengan lebih jelas. 
Jadual 2: Nilai skor min mengikut konstruk

\begin{tabular}{lcc}
\hline \multicolumn{1}{c}{ Instrumen } & Nilai skor min & Tahap \\
\hline Kebimbangan dalam penilaian matematik & 2.71 & Sederhana \\
Kebimbangan matematik dalam sosial atau kehidupan harian & 2.39 & Rendah \\
Kebimbangan dalam pemerhatian matematik & 2.47 & Rendah \\
Tahap kebimbangan (keseluruhan) & 2.53 & Sederhana \\
\hline
\end{tabular}

\section{Hubungan antara Tahap Kebimbangan Matematik dengan Pencapaian Matematik Pelajar Tingkatan Satu}

Ujian Kolmogorov-Smirnov yang dijalankan ke atas data menunjukkan taburan data adalah tidak normal dengan nilai sig < .05. Oleh itu, Ujian Korelasi Spearman rho digunakan untuk menganalisis hubungan antara tahap kebimbangan matematik dengan pencapaian pelajar tingkatan satu dalam matematik. Jadual 3 menunjukkan dapatan data bagi hubungan antara dua pemboleh ubah ini.

Jadual 3: Hubungan antara tahap kebimbangan matematik dengan pencapaian matematik pelajar tingkatan satu

\begin{tabular}{llc}
\hline & & Tahap kebimbangan matematik \\
\hline Pencapaian matematik UPSR & Pekali Korelasi & .103 \\
& Sig. (2-tailed) & .225 \\
& $\mathrm{~N}$ & 140 \\
\hline
\end{tabular}

Bagi kajian ini $(\mathrm{n}=140)$, korelasi antara tahap kebimbangan matematik $(M=2.53, S D=.571)$ dan pencapaian matematik pelajar dalam UPSR $(M=3.42, S D=1.011)$ adalah tidak signifikan dan sangat lemah, $\mathrm{r}=.103, \mathrm{p}=.225$. Pengkaji gagal menolak hipotesis nul. Bukti tidak mencukupi bagi menyatakan terdapat hubungan antara tahap kebimbangan matematik dengan pencapaian matematik pelajar tingkatan satu. Berdasarkan keputusan analisis kajian ini, kesimpulan dapat dibuat bahawa tahap kebimbangan matematik tidak berhubung kait dengan pencapaian matematik pelajar tingkatan satu.

\section{Perbincangan Kajian}

Kajian ini melihat kepada kebimbangan matematik dari tiga sudut, iaitu kebimbangan matematik dalam sosial atau kehidupan harian, penilaian matematik dan pemerhatian matematik. Dapatan kajian menunjukkan bahawa kebimbangan responden dari aspek aplikasi matematik dalam kehidupan harian adalah pada tahap sederhana. Tahap kebimbangan responden dalam penilaian dan pemerhatian matematik adalah rendah. Secara keseluruhannya, kebimbangan responden terhadap matematik berada pada tahap sederhana. Penemuan ini menyokong kajian pengkaji-pengkaji lepas yang menyimpulkan bahawa tahap kebimbangan matematik pelajar sekolah menengah rendah adalah sederhana. (Azizah, Mahmudi \& Renawati, 2019; Yavuz, 2018). Pada masa yang sama, kajian mendapati bahawa tidak terdapat hubungan antara tahap kebimbangan matematik dengan pencapaian matematik pelajar tingkatan satu. Dapatan ini selaras dengan dapatan kajian lepas yang menyatakan bahawa pelajar dengan pencapaian matematik rendah tidak semestinya menghadapi kebimbangan matematik yang tinggi. (Azizah, Mahmudi \& Retnawati, 2019; Mustaffa, 2017; Prodromou \& Frederiksen, 2018; Yahya \& Amir, 2018).

Walau bagaimanapun, dapatan kajian bercanggahan dengan kajian Amam, Darhim, Fatimah dan Noto (2019) di mana pelajar sekolah menengah rendah menonjolkan tahap rendah dalam kebimbangan terhadap matematik. Perbezaan dapatan ini boleh dipengaruhi oleh punca-punca seperti latar belakang responden dan pendekatan pembelajaran yang digunakan di sekolah atau negara tersebut. Kebimbangan pelajar sekolah menengah rendah menumpu kepada tahap sederhana dan rendah menunjukkan bahawa perasaan gelisah terhadap matematik mula dirasai apabila mereka melangkah ke peringkat sekolah menengah. Konsep matematik menjadi semakin sukar dan soalan kemahiran berfikir aras tinggi adalah lebih mencabar berbanding di peringkat sekolah rendah. Apabila pelajar melangkau ke peringkat universiti, 
kebimbangan mereka terhadap matematik turut meningkat dan mencatatkan tahap kebimbangan yang tinggi (Juniati \& Budayasa, 2020).

Walaupun keputusan matematik dalam UPSR responden kajian menjurus kepada peringkat lemah, tahap kebimbangan mereka terhadap matematik adalah sederhana. Persepsi dan minat pelajar terhadap subjek ini sedikit sebanyak mempengaruhi pencapaian mereka. Keputusan pelajar lemah juga boleh dipengaruhi oleh faktor-faktor seperti kebimbangan ujian, motivasi, daya ingatan dan kebolehan membaca yang terhad (Hunt \& Zakaria, 2018). Sesetengah pelajar mendapat markah yang tinggi juga menonjolkan simptom kebimbangan matematik (Yavuz, 2018). Tekanan daripada harapan ibu bapa dan diri mendorong kepada perasaan tertekan dan gementar sewaktu ujian (Rameli \& Kosnin, 2016). Sebagai akibatnya, pelajar cemerlang menghadapi kebimbangan matematik. Pada masa yang sama, kebimbangan matematik tidak kelihatan pada pelajar yang memperoleh keputusan yang lemah (Prodromou \& Frederiksen, 2018). Keinginan pelajar mempelajari sesuatu mata pelajaran bergantung kepada sikap dan motivasi mereka untuk mencabar diri. Minat pelajar terhadap matematik yang makin merudum menyebabkan mereka kurang memberi fokus sewaktu pembelajaran. Oleh demikian, kegelisahan yang wujud sewaktu berhadapan kegiatan matematik akan dirasai oleh sesiapa sahaja, tanpa mengira tahap pencapaian mereka dalam ujian.

Pada masa yang sama, kemahiran aritmetik berkait rapat dengan memori kerja seseorang. Keupayaan pelajar memproses dan menyelesaikan soalan mencabar akan menjejaskan penguasaan kemahiran matematik yang lebih tinggi (Dowker, Sarkar \& Looi, 2016). Pelajar yang menghadapi kesukaran dalam menyelesaikan masalah matematik akan mengalami kebimbangan matematik dan seterusnya menghindarkan mereka daripada berhadapan dengan cabaran ini. Disebabkan oleh perasaan takut akan matematik, mereka gagal menumpukan perhatian pada tugasan bersifat aritmetik. Kebolehan mereka mengingati pembelajaran matematik adalah terhad. Korelasi antara penurunan kapasiti memori kerja dengan peningkatan usia menjadikan pelajar sukar memproses dan mengingat semula kandungan yang telah dipelajari (Ambaranti \& Retnowati, 2019). Tambahan pula, sukatan pelajaran semakin kompleks di menengah atas dan pengajian tinggi. Mereka mengambil lebih banyak masa untuk memahami sesuatu konsep. Hal ini mengakibatkan kegelisahan mereka terhadap matematik turut bertambah. Walaupun pelajar hanya berada di peringkat menengah rendah, tahap kebimbangan matematik sederhana secara tidak langsung menunjukkan bahawa pelajar mula menghadapi masalah dalam menghayati konsep matematik.

\section{Implikasi Kajian}

Kajian-kajian lepas mengenai tahap kebimbangan matematik dan hubungannya dengan pencapaian matematik pelajar memberikan dapatan yang berlainan. Perbezaan dari segi dapatan kajian mencetuskan idea agar penyelidikan akan datang dijalankan bagi suatu tempoh yang lebih panjang. Dengan demikian, pengkaji dapat mengesan pola tahap kebimbangan pelajar dan memperoleh data lebih jitu. Kajian harus dijalankan ke atas sekolah dengan pencapaian matematik rendah. Dapatan kajian membantu sekolah memahami dan menolak kemungkinan fobia terhadap matematik menjadi penyumbang kepada pencapaian rendah dalam subjek ini. Walaupun kajian akan memakan masa panjang sehingga berbulan atau beberapa tahun, hasil kajian boleh digunakan oleh pihak sekolah dan Kementerian Pendidikan sewaktu merancang kurikulum sekolah. Tambahan pula, kajian ini hanya melihat kepada hubungan antara tahap kebimbangan matematik dengan pencapaian matematik dalam pelajar tingkatan satu. Pengkaji mencadangkan agar kajian akan datang mengintegrasikan kaedah PdP berbantukan teknologi bagi menangani kebimbangan matematik dalam kalangan pelajar. Langkah lanjutan harus diambil bagi membantu pelajar mengurangkan kegelisahan mereka apabila berhadapan dengan aktiviti melibatkan matematik. Memandangkan pelajar zaman ledakan teknologi terdedah kepada pelbagai aplikasi dalam kehidupan harian mereka, pengintegrasian teknologi dapat memberi pendedahan kepada mereka tentang hubungan antara matematik dengan realiti kehidupan dengan lebih jelas. Intervensi awal juga memberi peluang kepada pelajar mengubah persepsi mereka dan mendalami serta menikmati keindahan matematik. 


\section{Kesimpulan}

Hasil kajian mendapati bahawa tahap kebimbangan pelajar terhadap matematik adalah pada kadar sederhana. Namun demikian, tidak terdapat hubungan antara tahap kebimbangan matematik dengan pencapaian pelajar dalam matematik. Pelajar yang mendapat keputusan cemerlang ataupun lemah turut menghadapi kegelisahan dalam matematik. Meskipun sesetengah konsep matematik merupakan sebahagian daripada kehidupan kita, pelajar terpaksa berhadapan dengan perasaan gelisah apabila berhadapan dengan aktiviti melibatkan aritmetik. Keadaan ini akan menjejaskan persepsi dan minat mereka terhadap matematik. Langkah pengesanan awal membantu guru dan pelajar dalam menangani masalah ini. Fobia terhadap matematik yang tidak dirawat akan berlarutan dan menjadi semakin teruk. Perasaan takut ini juga berupaya menjejaskan kehidupan harian dan pilihan profesion mereka kemudian hari. Oleh yang demikian, isu kebimbangan matematik tidak harus dipandang enteng tetapi masyarakat, terutamanya para pendidik, patut melengkapkan diri dengan pengetahuan tentang fobia ini.

\section{Rujukan}

Amam, A., Darhim, D., Fatimah, S. \& Noto, M. S. (2019). Math anxiety performance of the 8th grade students of junior high school. Journal of Physics: Conference Series, 1157(4), 042099. IOP Publishing.

Ambaranti, F., \& Retnowati, E. (2019). Exploring mathematics anxiety among senior high school students. Journal of Physics: Conference Series 1200(1), 012004. IOP Publishing.

Azizah, L. N., Mahmudi, A. \& Retnawati, H. (2019). Profile of students' mathematics anxiety. Journal of Physics: Conf. Series 1320012105.

Carey, E., Hill, F., Devine, A., \& Szucs, D. (2016). The chicken or the egg? The direction of the relationship between mathematics anxiety and mathematics performance. Frontiers in Psychology 6 , 1987.

Carey, E., Devine, A., Hill, F., Dowker, A., McLellan, R. \& Szucs, D. (2019). Understanding mathematics anxiety: Investigating the experiences of UK primary and secondary school students. Retrieved from https://www.repository.cam.ac.uk/bitstream/handle/1810/290514/Szucs\%2041179\%20\%20Main\%20Public\%20Output\%208\%20March\%202019.pdf?sequence=1\&isAllowed=y

Chua, Y. P (2013). Asas statistik penyelidikan: Analisis data skala Likert. (2 ${ }^{\text {nd }}$ ed.). Malaysia: McGrawHill Education (Malaysia) Sdn. Bhd.

Chua, Y. P. (2014a). Asas statistik penyelidikan. (3 ${ }^{\text {rd }}$ ed.). Malaysia: McGraw-Hill Education (Malaysia) Sdn. Bhd.

Chua, Y. P. (2014b). Kaedah penyelidikan. (3 ${ }^{\text {rd }}$ ed.). Malaysia: McGraw-Hill Education (Malaysia) Sdn. Bhd.

Darusalam, G. \& Hussin, S. (2018). Metodologi penyelidikan dalam pendidikan: Amalan dan analisis kajian. ( $2^{\text {nd }}$ ed.). Kuala Lumpur: Penerbit Universiti Malaya.

Delgado, I., Espinoza, J., \& Fonseca, J. (2017). Mathematics anxiety in college students in Costa Rica and their relationship with academic achievement and socio-demographic variables. Journal of Educational Psychology-Propositos y Representaciones, 5(1), 301-324.

Deringol, Y. (2018). Primary school students' mathematics motivation and anxieties. Cypriot Journal of Educational Sciences, 13(4), 537-548.

Dowker, A., Sarkar, A. \& Looi, Chung Yen. (2016). Mathematics anxiety: What have we learned in 60 years?. Frontiers In Psychology, 7, 508.

Hunt, T. E., Clark-Carter, D. \& Sheffield, D. (2011). The development and part validation of a UK scale for mathematics anxiety. Journal of Psychoeducational Assessment, 29(5), 455-466.

Hunt, W. C. \& Zakaria, E.. (2018). Hubungan antara kebimbangan matematik dan pencapaian matematik murid sekolah rendah. Prosiding Seminar Kebangsaan Majlis Dekan Pendidikan Universiti Awam 2018, 197-207.

Juniati, D. \& Budayasa, I. K. (2020). Working memory capacity and mathematics anxiety of mathematics students and its effect on mathematics achievement. Journal for the Education of Gifted Young Scientists, 8(1), 279-291. 
Kementerian Pendidikan Malaysia. (2015). Dokumen standard kurikulum dan pentaksiran matematik tingkatan 1. Putrajaya: Bahagian Pembangunan Kurikulum.

Krejcie, R. V. \& Morgan, D. W. (1970). Determining sample size for research activities. Educational and Psychological Measurement, 30(3), 607-610.

Lee, J. (2009). Universals and specifics of math self-concept, math self-efficacy, and math anxiety across 41 PISA 2003 participating countries. Learning and individual differences, 19(3), 355-365.

Majlis Keselamatan Negara. (2018). Kenyataan media majlis keselamatan negara, jabatan perdana menteri. Retrieved from https://www.pmo.gov.my/wp-content/uploads/2020/03/PERGERAKANKAWALAN-COVID19-amended-18032020-UPDATED-12.12AM.pdf.pdf.

Mandal, A. K. (2020). Mathematics anxiety and academic achievement of students at secondary stage of education. Studies in Indian Place Names, 40(56), 133-152.

Mutlu, Y. (2019). Math anxiety in students with and without math learning difficulties. International Electronic Journal of Elementary Education, 11(5), 471-475.

Mustaffa, H. (2017). Hubungan antara kebimbangan matematik dengan motivasi dan prestasi pelajar pada subjek matematik. National Pre University Seminar 2017, 62-70.

OECD. (2013). Mathematics self-beliefs and participation in mathematics-related activities. PISA 2012 Results: Ready to Learn (Volume III), Students' Engagement, Drive and Self-Beliefs, 87-112.

Passolunghi, M. C., Caviola, S., De Agostini, R., Perin, C. \& Mammarella, I. C. (2016). Mathematics anxiety, working memory, and mathematics performance in secondary-school children. Frontiers in psychology, 7, 42 .

Prahmana, R. C. I., Sutanti, T., Wibawa, A. P., \& Diponegoro, A. M. (2019). Mathematical anxiety among engineering students. Infinity Journal, 8(2), 179-188.

Prodromou, T. \& Frederiksen, N. (2018). The effects of mathematics anxiety on primary students. Mathematics Education Research Group of Australasia.

Puteh, M. \& Khalin, S. Z. (2016). Mathematics anxiety and its relationship with the achievement of secondary students in Malaysia. International Journal of Social Science and Humanity, 6(2), 119.

Rameli, M. R. M. \& Kosnin, A. M.. (2016). Malaysian school students' math anxiety: application of rasch measurement model.

Retrieved from https://www.researchgate.net/profile/Mohd_Rustam_Mohd_Rameli3/publication/321873451_Mala ysian_School_Students'_Math_Anxiety_Application_of_Rasch_Measurement_Model/links/5a3746 eba6fdcc769fd7f563/Malaysian-School-Students-Math-Anxiety-Application-of-RaschMeasurement-Model.pdf

Yahya, S. Z. \& Amir, R. (2018). Kebimbangan matematik dan pencapaian matematik Tambahan [Mathematics anxiety and additional mathematics performance]. Journal of Nusantara Studies (JONUS), 3(2), 124-133.

Yavuz, G. (2018). Mathematics anxiety of ninth grade students. Journal of Education and Training Studies, 6(5), 21-27. 